\title{
The Efficiency of Zakat Management Organizations in Indonesia: Data Envelopment Analysis Approach
}

\author{
Safaah Restuning Hayati ${ }^{1^{*}}$, Syah Amelia Manggala Putri ${ }^{2}$ \\ ${ }^{1,2}$ Department of Islamic Economics, Universitas Muhammadiyah, Yogyakarta, Indonesia
}

Submitted: May 1, 2019, Accepted: January 8, 2020, Published: January 11, 2020

\begin{abstract}
Efficiency can be defined as the ratio between output and input. A company is said to be efficient if it can produce greater output when compared to other companies that use the same amount of input or produce the same amount of output, but the number of inputs used is less compared to other company inputs. This study aims to analyze the efficiency of Zakat Management Organizations (ZMO) in Indonesia and to find sources of inefficiency of Zakat Management Organizations (ZMO). The method used is Data Envelopment Analysis (DEA) using software called Banxia Frontier Analyst (BFA). The analysis concluded that based on CRS assumptions, there were 7 DMUs that had achieved efficiency with a score of $100 \%$. The seven DMUs are BAZNAS 2018, PKPU 2015, PKPU 2016, Rumah Zakat 2016, Rumah Zakat 2017, Rumah Zakat 2018 and Yatim Mandiri 2016. Meanwhile, with the assumption of VRS, there are 9 efficient DMUs namely BAZNAS 2015, BAZNAS 2018, PKPU 2015, PKPU 2015 2016, Rumah Zakat 2015, Rumah Zakat 2016, Rumah Zakat 2017, Rumah Zakat 2018, and Yatim Mandiri 2016. Sources of inefficiency in the Organization of Zakat Management (ZMO) are inputs or costs, including personnel costs, socialization costs, and other operational costs. This has implications for the organization's ability to optimally combine existing resources to achieve maximum output.
\end{abstract}

Keywords: efficiency, zakat management organization, data envelopment analysis (DEA)

\begin{abstract}
Abstrak
Efisiensi dapat didefinisikan sebagai perbandingan antara output dan input. Suatu Perusahaan dikatakan efisien jika dapat menghasilkan output yang lebih besar jika dibandingkan dengan perusahaan lain yang menggunakan jumlah input yang sama atau menghasilkan jumlah output yang sama, tetapi jumlah input yang digunakan lebih sedikit dibandingkan dengan input perusahaan lain. Penelitian ini bertujuan untuk menganalisis tingkat efisiensi Organisasi Pengelola Zakat (OPZ) di Indonesia dan untuk menemukan sumber inefisiensi Organisasi Pengelola Zakat (OPZ). Metode yang digunakan adalah Data Envelopment Analysis (DEA) dengan memakai sofware bernama Banxia Frontier Analyst (BFA). Hasil analisis menyimpulkan bahwa berdasarkan asumsi CRS, terdapat 7 DMU yang sudah mencapai efisiensi dengan skor 100\%. Ketujuh DMU tersebut adalah BAZNAS 2018, PKPU 2015, PKPU 2016, Rumah Zakat 2016, Rumah Zakat 2017, Rumah Zakat 2018 dan Yatim Mandiri 2016. Sedangkan dengan asumsi VRS, terdapat 9 DMU yang efisien yaitu BAZNAS 2015, BAZNAS 2018, PKPU 2015, PKPU 2016, Rumah Zakat 2015, Rumah Zakat 2016, Rumah Zakat 2017, Rumah Zakat 2018, dan Yatim Mandiri 2016. Sumber penyebab inefisiensi Organisasi Pengelola Zakat (OPZ) adalah input atau biaya-biaya, meliputi biaya personalia, biaya sosialisasi, dan biaya operasional lainnya. Hal ini berimplikasi pada kemampuan organisasi dalam mengkombinasikan sumber daya yang ada secara optimal untuk mencapai output secara maksimal.
\end{abstract}

Kata kunci: efisiensi, organisasi pengelola zakat, data envelopment analysis (DEA)

\footnotetext{
* Corresponding author

restuninghayati@yahoo.com
}

ISSN 2087-7013

ISSN 2527-8304 


\section{INTRODUCTION}

The majority of Indonesia's population is Muslim. Based on the 2010 population census data, the total Muslim population was $207,176,162$ people or reached $87.18 \%$ of the total population of Indonesia. A Muslim has an obligation to carry out the five pillars of Islam, one of which is to pay zakat. For this reason, zakat is obligatory such as prayer and fasting. The large number of Muslim population in Indonesia is in line with the large potential of zakat.

Zakat potential can reach $3.4 \%$ of the total Gross Domestic Product (GDP) if zakat is determined as a tax deduction (Sudibyo, 2018). The potential magnitude in question is in 2017 which is 462 trillion rupiah. This potential value is higher than the current zakat potential, where the applicable regulation is zakat as a deduction from taxable income (Puskas BAZNAS, 2019). The different levels of zakat potential can be seen in the table below:

Table 1. The Potential of Zakat and GDP Level Tax Incentives Current

\begin{tabular}{|c|c|c|}
\hline & Current Regulation & Ideal Tax Incentives \\
\hline $\begin{array}{l}\text { Tax } \\
\text { Incentives }\end{array}$ & $\begin{array}{l}\text { Zakat as a deduction } \\
\text { from taxable income } \\
(\mathrm{PKP})\end{array}$ & Zakat as a tax deduction \\
\hline $\begin{array}{l}\text { Potential of } \\
\text { Zakat }\end{array}$ & $1.57 \%$ of GDP & $3,4 \%$ of GDP \\
\hline
\end{tabular}

Source: Sudibyo, 2018.

The potential of zakat in Indonesia has not been supported by the achievement of zakat accumulation in the field. Hence, there is a very high gap between the potential and the realities of accumulation. This fact is supported by recent data which indicates a sufficiently clear distance between the potential of zakat and the actual accumulation. Moreover, it can be seen from the actual data on the collection of zakat, infaq and shadaqah by the official ZMO in 2016 which only reached about IDR 5 trillion or less than 2.3 percent of its potential (Puskas BAZNAS, 2019). While the amount of zakat in 2016 collected was only around IDR 4 trillion. The following is data on the development of the amount of zakat funds collected in Indonesia:

Table 2. Zakat Collection Individual and Institution Year Zakat Collection

\begin{tabular}{ccc}
\hline Year & Zakat Collection Individual & Zakat Collection Institution \\
\hline 2013 & 23.320 .146 .044 & 19.091 .201 .735 \\
\hline 2014 & 117.085 .731 .136 & 35.916 .501 .176 \\
\hline 2015 & 2.217 .083 .240 .925 & 557.823 .481 .692 \\
\hline 2016 & 3.395 .248 .274 .318 & 620.546 .547 .627 \\
\hline
\end{tabular}

Source: Puskas BAZNAS, 2018. 
The great potential of zakat has in fact not been realized optimally. In 2017, the amount of zakat, infaq, and alms (ZIS) collected was IDR 6.2 trillion. Even though there was an increase of around 24\% from the collection of ZIS in 2016 which amounted to IDR 5 trillion, but the collection was even relatively small when compared to the potential for collecting zakat. Based on this explanation, there is clearly a gap between the potential for zakat and zakat funds collected. This gap is influenced by several things, one of them there is still public distrust of zakat institution which is considered weak and unprofessional. Some zakat institutions (especially unofficial ones) in some regions only accept the collection and do not engage in an active and progressive movement regarding utilization of zakat especially on productive side. Thus, it is important to set the positioning of zakat institutions especially government agencies and non-governmental organizations to maximize the role of institutional strengthening management (Puskas BAZNAS, 2019).

The low amount of zakat that has been collected compared to the existing potential, may reflect the lack of optimal performance of ZMO. According to Hafidhuddin (2011), the potential for zakat can be explored through four steps: (1) socialization and education to the public; (2) strengthening amil zakat so that it becomes trustworthy, and professional amil; (3) distribution of zakat that is right on target in accordance with sharia provisions and takes into account transparent management aspects; (4) synergy and coordination among the ZMO groups. The role of amil zakat institutions in collecting zakat funds is very important so that the great zakat potential can be realized. For this reason, a zakat institution that has good and efficient management is needed. Efficiency is important so that zakat institutions can collect as much zakat funds as possible using existing resources.

There are several previous studies that are relevant to this study in the last ten years. Research on the efficiency of zakat organizations in Malaysia has been carried out by Noor, Rasool, Ali, and Rahman (2015). A total of 303 respondents participated in the study, which consisted of zakat beneficiaries, staff, and department heads and stakeholders from two zakat institutions. The research found adequate resources available for zakat organizations. Performance and types of programs in zakat management organizations are important so that zakat organizations are more efficient. This study reports that zakat organizations can improve the quality of life of beneficiaries (mustahik) for the better. This can be said, the management of zakat management has been efficient.

Research with the same theme was also carried out by Wahab and Rahman (2011) by presenting a conceptual model of the efficiency and governance of zakat institutions that are 
responsible for collecting, managing and distributing zakat in Malaysia. Evaluation for zakat institutions is very important to be carried out so that the Islamic financial system functions effectively and efficiently to achieve noble goals, namely social and economic justice through proper and equitable distribution of wealth.

Rustyani and Rosyidi (2018) have conducted research with the aim to measure the level of efficiency and productivity of zakat institutions in Indonesia. The results of the MPI analysis show that in the first year two LAZs experienced a decline in productivity, namely LAZ A1Azhar and PKPU. The other four LAZs saw an increase in productivity, namely LAZ YDSF, ACT, Rumah Yatim, and Rumah Zakat. In the second year, three LAZs experienced a rise in productivity, namely LAZ Al-Azhar, PKPU, and Rumah Zakat, while the other three LAZs experienced a decrease in productivity, namely LAZ YDSF, ACT, and Rumah Yatim.

Budiantoro, Lutfi, and Herianingrum (2018) have also examined the efficiency of zakat institutions with the Stochastic Frontier approach. The efficiency results regarding BAZNAS's average receipt of zakat for the period 2002-2016, using a parametric method (SFA), amount to 94.98 percent, which means that there is still a 5.02 percent chance that this could be optimized to achieve the highest operational efficiency level possible for BAZNAS.

Inspired by previous studies, this study examines the level of efficiency of zakat management organizations (ZMO) in Indonesia using the Data Envelopment Analysis (DEA) approach. The samples used are the Badan Amil Zakat Nasional (BAZNAS), Rumah Zakat, Pos Keadilan Peduli Umat (PKPU), and Yatim Mandiri, with research periods from 2015 to 2018. The research object, methodology, and research period are different from previous studies. The problem statements for this study are to find the efficiency of ZMO and to find the factors that cause inefficiencies in ZMO.

\section{METHODS}

This type of research is quantitative with a nonparametric approach. The method used is Data Envelopment Analysis (DEA) using Banxia Frontier Analyst (BFA) statistical software. Data Envelopment Analysis (DEA) is a nonparametric method that uses a linear program model to calculate the ratio of output and input ratios for all units, or commonly referred to as the Decision Making Unit(DMU) compared.

The DEA method has two commonly used models, namely the CCR or Charnes, Cooper, and Rhoodes models developed in 1978 and the BCC or Banker, Charnes and Cooper models in 1984. The CCR model uses the CRS (Constant Return to Scale) approach which assumes that any increase in input proportional to a certain percentage will increase output by 
the same percentage. This assumption only applies if each business unit observed has been producing at its maximum capacity (optimum scale). Efficiency with this CRS assumption results in overall technical efficiency. Whereas BCC uses the VRS (Variable Return to Scale) approach and produces pure technical efficiency (Tanjung \& Devi, 2013).

The population of this study is the Zakat Management Organization (ZMO), with the condition that the ZMO has published financial reports and is officially registered in Puskas BAZNAS. In 2017 the number of ZMO registered at Puskas BAZNAS was 18 BAZ and LAZ. The samples in this study were four Zakat Management Organizations (ZMO), namely the Badan Amil Zakat Nasional (BAZNAS), Pos Keadilan Peduli Umat (PKPU), Yatim Mandiri and Rumah Zakat. This amount was taken by purposive sampling technique. The sample is based on the following considerations: 1) There are similarities in the components of the input and output used by the institution, and because the Data Envelopment Analysis (DEA) method requires so. 2) Limited data available, because there are still many Zakat Management Organizations (ZMO) that have not published detailed and complete financial statements in 2015-2018.

Data Envelopment Analysis (DEA) does not require a minimum number of samples to be examined, because the DEA method measures the relative efficiency or best practice of the DMU (Decision Making Unit) analyzed. The DMU or Decision Making Unit in the DEA is introduced as a representation of the operational unit (business unit) to be assessed. DMU can be any entity (type of organization) that can change inputs (resources) into outputs (results). The number of DMU must be $\geq$ of the total number of input and output variables. Every ZMO with a different year, is considered a separate DMU. There are usually more than five DMU units in order to avoid self-identifiers (Tanjung \& Devi, 2013).

Measurement of the value of efficiency in this study uses a production approach, with input and output variables which can be explained in the following table:

Table 3. Specifications of Input and Output Variables with the Production Approach

\begin{tabular}{|c|c|c|}
\hline Variable Type & Component & Definition \\
\hline \multirow[t]{2}{*}{ Output Variable } & Collected Funds $\quad\left(\mathrm{Y}_{1}\right)$ & $\begin{array}{l}\text { The total collection of funds is bound and } \\
\text { not }\end{array}$ \\
\hline & Funds Disbursed & $\begin{array}{l}\text { The total distribution of funds is bound and } \\
\text { not }\end{array}$ \\
\hline \multirow[t]{3}{*}{ Input Variable } & Personnel Costs $\left(\mathrm{X}_{1}\right)$ & Amil salary and \\
\hline & $\begin{array}{l}\text { Socialization Costs } \\
\left(\mathrm{X}_{2}\right)\end{array}$ & ZIS socialization and literacy costs \\
\hline & $\begin{array}{l}\text { Other Operating Costs } \\
\left(\mathrm{X}_{3}\right)\end{array}$ & $\begin{array}{l}\text { Office expenses, transportation costs, the } \\
\text { burden of human resource development, } \\
\text { other expenses }\end{array}$ \\
\hline
\end{tabular}




\section{RESULT AND DISCUSSION}

The development of zakat funds collected during the observation period continued to increase, although only slightly. The following is data on the collection of zakat infaq and shadaqah funds by four Zakat Management Organizations (ZMO) which are the samples of this study.

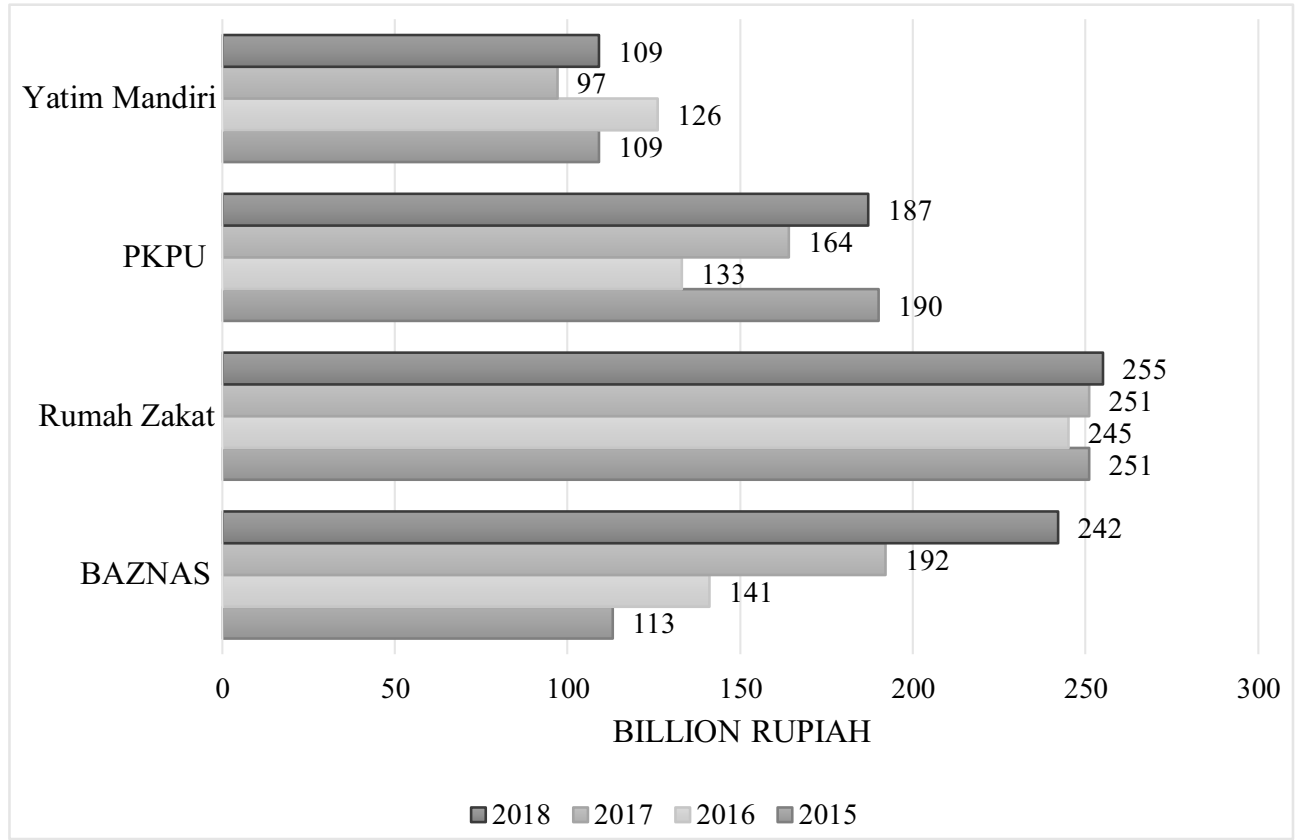

Figure 1. Development of Collecting Zakat Infaq Sadaqah (ZIS) Year 2015-2018 Source: ZMO Financial Report, processed.

Based on the data above, the collection of ZIS funds at BAZNAS and Rumah Zakat continues to increase. As seen in 2016, BAZNAS has collected ZIS funds totaling 242 billion rupiahs and Rumah Zakat totaling 255 billion rupiahs. Whereas ZIS fundraising at PKPU and Yatim Mandiri tends to fluctuate. In fact, the collection of ZIS funds in PKPU in 2016 experienced a significant decline of around 57 billion rupiahs. Judging from the amount of ZIS funds collected, ZMO's hard work has gotten good results.

Efficient in raising funds could be seen from with limited budget, ZMO can raise ZIS funds or donations in large amounts. This is also related to the efficiency of administrative costs, that ZMO must reduce administrative costs as low as possible. For this reason, ZMO needs to make clear rules relating to administrative expenditure mechanisms within ZMO to minimize unnecessary expense (IMZ, 2010). 
Zakat Management Organization is demanded to continuously improve its performance. According to Hidayat (2014), one way to measure performance is through efficiency levels. The level of efficiency can provide a picture of the performance of a company or organization. An efficient company means good performance, and vice versa. Efficient Zakat Management Organization can increase the trust of muzakki, that the zakat infaq and shadaqah (ZIS) funds that have been paid and have been managed well and have been distributed on target. Furthermore, the results of the Data Envelopment Analysis on the level of ZMO efficiency are specified in the following table:

Table 4. Efficiency Level of Zakat Management Organization (ZMO)

\begin{tabular}{|c|c|c|c|c|}
\hline \multirow{2}{*}{$\begin{array}{c}\text { DMU } \\
\text { (Decision Making Unit) } \\
\text { Unit Name }\end{array}$} & \multicolumn{2}{|c|}{$\begin{array}{c}\text { CCR/CRS } \\
\text { (Constant Return to Scale) }\end{array}$} & \multicolumn{2}{|c|}{$\begin{array}{c}\mathrm{BCC} / \mathrm{VRS} \\
\text { (Variable Return to Scale) }\end{array}$} \\
\hline & Score & Efficient & Score & Efficient \\
\hline BAZNAS 2015 & $55,8 \%$ & & $100 \%$ & $\sqrt{ }$ \\
\hline BAZNAS 2016 & $78,2 \%$ & & $79,7 \%$ & \\
\hline BAZNAS 2017 & $87,3 \%$ & & $87,8 \%$ & \\
\hline BAZNAS 2018 & $100 \%$ & $\sqrt{ }$ & $100 \%$ & $\sqrt{ }$ \\
\hline PKPU 2015 & $100 \%$ & $\sqrt{ }$ & $100 \%$ & $\sqrt{ }$ \\
\hline PKPU 2016 & $100 \%$ & $\sqrt{ }$ & $100 \%$ & $\sqrt{ }$ \\
\hline PKPU 2017 & $78,3 \%$ & & $78,6 \%$ & \\
\hline PKPU 2018 & $83,2 \%$ & & $83,8 \%$ & \\
\hline Rumah Zakat 2015 & $98,7 \%$ & & $100 \%$ & $\sqrt{ }$ \\
\hline Rumah Zakat 2016 & $100 \%$ & $\sqrt{ }$ & $100 \%$ & $\sqrt{ }$ \\
\hline Rumah Zakat 2017 & $100 \%$ & $\sqrt{ }$ & $100 \%$ & $\sqrt{ }$ \\
\hline Rumah Zakat 2018 & $100 \%$ & $\sqrt{ }$ & $100 \%$ & $\sqrt{ }$ \\
\hline Yatim Mandiri 2015 & $85,5 \%$ & & $86,3 \%$ & \\
\hline Yatim Mandiri 2016 & $100 \%$ & $\sqrt{ }$ & $100 \%$ & $\sqrt{ }$ \\
\hline Yatim Mandiri 2017 & $36,2 \%$ & & $39,0 \%$ & \\
\hline Yatim Mandiri 2018 & $33,9 \%$ & & $42,8 \%$ & \\
\hline
\end{tabular}

Source: BFA Output, 2019.

The results of the efficiency analysis in the table above show that with the CRS (Constant Return to Scale) model there are nine DMUs studied that have an efficiency value of less than $100 \%$, while the other seven DMUs have a score of 100\%. Seven DMUs which are worth 100\% and can be said to be efficient, namely BAZNAS 2018, PKPU 2015, PKPU 2016, Rumah Zakat 2016, Rumah Zakat 2017, Rumah Zakat 2018 and Yatim Mandiri 2016. Whereas the other nine DMU are inefficient. As such, there are only seven DMUs that are efficient overall (overall technicall efficiency). According to Hidayat (2014), there are three factors that 
cause efficiency, namely: (1) if with the same input can produce greater output, (2) with smaller inputs can produce the same output, and (3) with input that is greater can produce a greater amount of output.

Professionalism of the management of zakat or amil zakat is very important in developing zakat institutions. In fact, the importance of the existence of amil zakat is explicitly found in the Al-Qur'an Surah At-Taubah verse 60. In addition to being trustworthy and honest, an amil is required to think visionary and creative in the digital era like today in order to spark right programs on target, so that ZIS funds can be collected as optimally and efficiently as possible.

This is in accordance with research by Mubtadi and Susilowati (2018) that professionals on Board positively affect disbursement efficiency, cost efficiency, and time efficiency. Frequency of board meetings has a positive effect on disbursement efficiency, a negative effect on cost efficiency, and a positive effect on time efficiency. Amara and Atia (2016) stated that the efficiency of Zakat Institutions is not determined by the size of the board but that it is based on the board policies produced during regular meetings.

Furthermore, the results of the efficiency analysis with the Variable Return to Scale (VRS) model show that there are nine DMUs that have a score of $100 \%$ or efficient. The nine DMUs are BAZNAS 2015, BAZNAS 2018, PKPU 2015, PKPU 2016, Rumah Zakat 2015, Rumah Zakat 2016, Rumah Zakat 2017, Rumah Zakat 2018, and Yatim Mandiri 2016. Thus there are nine DMUs that are technically efficient. The nine efficient DMUs on the technical level have designed a structure that enables the organization's potential to grow further in order to increase the capability and contribution of benefits in the future. This Zakat Management Organization (ZMO) is filled with management who generally have the awareness and interest to develop zakat fund management and work professionally to achieve the goals (Khasanah, 2010).

According to Ascarya and Yumanita (2006), technical efficiency is only one component of overall economic efficiency. However, in order to achieve economic efficiency, a company must be technically efficient. In order to achieve maximum profits, a company must produce output to the maximum with a certain number of inputs (technical efficiency) and produce output with the right combination. Based on the results of the Data Envelopment Analysis (DEA) analysis with CRS and VRS models, there are several ZMOs that are already efficient. The following is a picture of the distribution of scores for each DMU, both efficient and inefficient: 


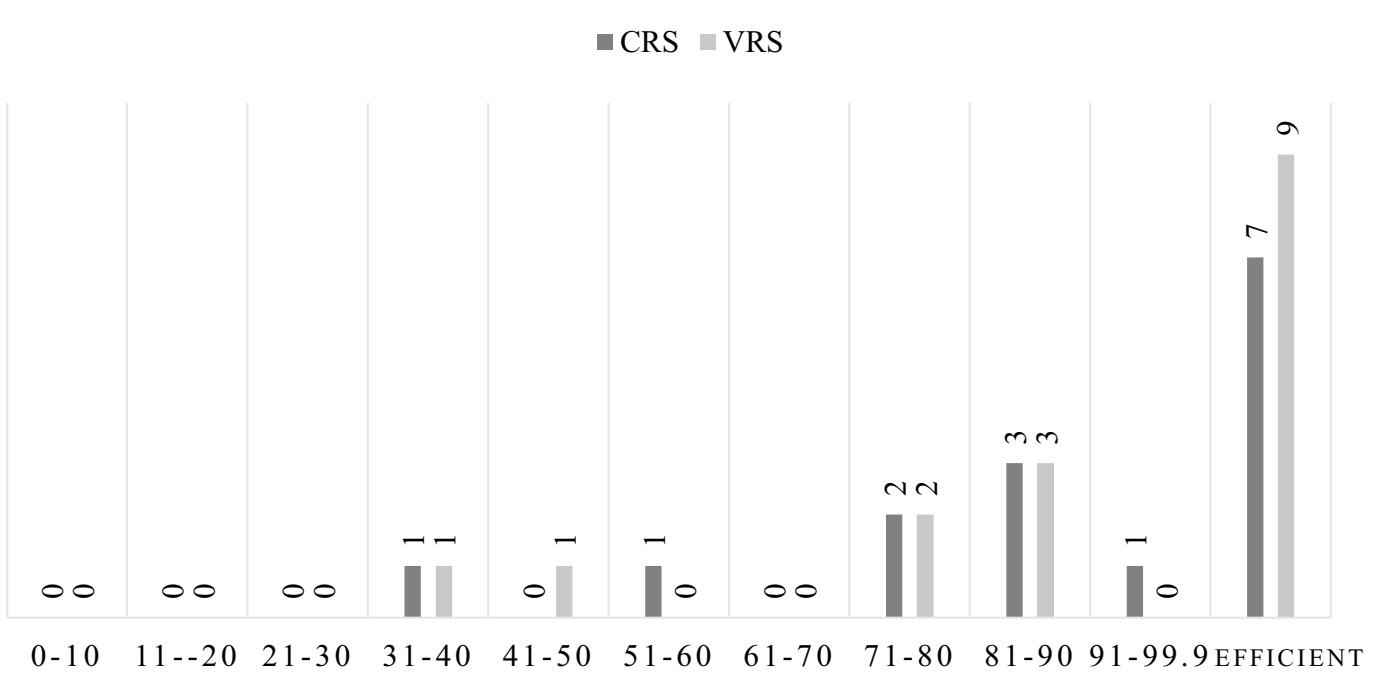

Figure 2. Distribution of Scores

Source: BFA2019 output, processed.

Based on the picture above, in the CRS model the majority of DMUs that became the study sample were in an inefficient position because the score was less than $100 \%$. Whereas seven DMUs have a score of $100 \%$ which means efficient. Furthermore, the majority of DMU models have a score of $100 \%$ which means efficient. The number of DMUs referred to is nine units.

One factor that determines the success of an organization is efficiency in operational, managerial, and financial (economic). Some Zakat Management Organizations (ZMO) are more efficient than others because of better management, more efficient technology, or more motivated and professional human resources. On the side of fund raising, diversification and innovation efforts are needed so that the number of muzakki and donors increases, so that the amount of funds raised also increases. Going forward, it is expected that amil's operational costs will not be taken from zakat funds but amil is able to finance himself from the results of operations using non-zakat funds (IMZ, 2010).

Based on the results of the analysis of the level of efficiency shows a lot of inefficient DMU. In the Data Envelopment Analysis (DEA) the source of inefficiency can be analyzed through one of the BFA (Banxia Frontier Analyst) outputs. One of the outputs is the total potential improvement in the following table:

Table 5. Total Potential Improvements

Variable Type

CCR/CRS

BCC/VRS

Total Potential Improvements

\begin{tabular}{lll}
\hline Output $1\left(\mathrm{Y}_{1}\right)$ & $37,37 \%$ & $31,17 \%$
\end{tabular}




\begin{tabular}{lcc}
\hline Output 2 (Y 2) & $44,32 \%$ & $42,75 \%$ \\
\hline Input 1 ( $\left.\mathrm{X}_{1}\right)$ & $-0,34 \%$ & $-8,45 \%$ \\
\hline Input 2 (X 2) & $-16,55 \%$ & $-15,83 \%$ \\
\hline Input 3 (X 3) & $-1,42 \%$ & $-1,8 \%$ \\
\hline
\end{tabular}

Source: BFA 2019 output, processed.

Based on the above data, it is known that in the CRS model to achieve $100 \%$ efficiency, it is necessary to reduce input $1\left(\mathrm{X}_{1}\right)$ by $0.34 \%$, input $2\left(\mathrm{X}_{2}\right)$ reduction by $16.55 \%$ and reduction of input $3\left(\mathrm{X}_{3}\right)$ by $1.42 \%$. While on the output side, it is necessary to increase output $1\left(\mathrm{Y}_{1}\right)$ by $37.37 \%$ and output $2\left(\mathrm{Y}_{2}\right)$ needs to be increased by $44.32 \%$. Whereas in the VRS model it can be seen that to achieve $100 \%$ efficiency, a reduction of input $1\left(\mathrm{X}_{1}\right)$ of $8.45 \%$ is required, a reduction of input $2\left(\mathrm{X}_{2}\right)$ of $15.83 \%$, and a reduction of input $3\left(\mathrm{X}_{3}\right)$ of $1.8 \%$.

On the output side, to achieve a 100\% efficiency level it is necessary to increase output 1 $\left(\mathrm{Y}_{1}\right)$ by $31.17 \%$ and increase output $2\left(\mathrm{Y}_{2}\right)$ by $42.75 \%$. Additional output can be done through the use of digital technology and social media. This is consistent with the results of Djaghballou, Djaghballou, Larbani, and Mohamad (2018) research on the efficiency of collecting zakat funds in Algeria. His research concluded that the Algerian zakat fund has great potential to further increase output through improving technology and capital equipment. This is different from the research results of Wahyuni (2016) and Rusydiana and Al-Farisi (2016) that based on the production approach measurement, sources of inefficiency of zakat institutions aside from costs also come from the distribution of zakah funds to ashnaf.

This is also not much different from the results of Al-Ayubi, Ascarya, and Possumah's study (2018) that the problems of increasing amil zakat institutions are the cost of socialization, the number of volunteers, the amount of zakat collected, and the consumptive distribution of zakat, which cumulatively reduces intermediary function of zakat institutions. Institutions must solve this problem to improve the efficiency of zakat institutions. Likewise with the research of Budiantoro, Lutfi, and Herianingrum (2018), it is emphasized that amil zakat institutions pay more attention to factors that affect the level of efficiency in terms of the receipt and distribution of zakat funds. It is known that the efficiency of receiving zakat funds is influenced by operational costs, while the efficiency of zakat fund distribution is influenced by total assets. Both of these variables must get the main attention in order to improve efficiency.

Related to personnel costs $\left(X_{1}\right)$, Hosen and Rahmawati (2016) stated that human resources costs should be a top priority when determining what needs to be spent and what needs to be cut. One input that needs to be reduced is the cost of socialization. For this reason, ZMO must be careful and precise in determining which media will be used to socialize their superior 
programs in order to attract muzakki to pay zakat through the ZMO. Internal ZMO must be able to measure and evaluate the effectiveness of each tool by comparing other tools. Based on the results of the evaluation, several tools or media that have been proven to be effective and efficient in collecting funds and with the lowest costs can be selected (IMZ, 2010).

Based on the data above, it can be concluded that the source of inefficiency is the input that needs to be reduced and the output that needs to be increased. This is in accordance with the opinion of Hidayat (2014), that the causes of an organization or company are less efficient due to two things, namely: (1) failure to use resources efficiently or inefficiencies in use; and (2) the company's failure to optimally combine these resources.

\section{CONCLUSION}

Based on the results of the study it can be concluded that with the CRS model there are seven efficient DMUs, namely BAZNAS 2018, PKPU 2015, PKPU 2016, Rumah Zakat 2016, Rumah Zakat 2017, Rumah Zakat 2018 and Yatim Mandiri 2016. While research with VRS models there are nine DMUs efficient namely BAZNAS 2015, BAZNAS 2018, PKPU 2015, PKPU 2016, Rumah Zakat 2015, Rumah Zakat 2016, Rumah Zakat 2017, Rumah Zakat 2018, and Yatim Mandiri 2016. The causes of DMU inefficiency sourced from input variables that need to be reduced. Input variables are costs, such as personnel costs, socialization costs, and operational costs. To achieve an efficiency score of $100 \%$ on the CRS model requires a reduction in input 1 of $0.34 \%$, input 2 of $16.55 \%$ and input 3 of $1.42 \%$. For the VRS model, we need to reduce input 1 by $8.45 \%$, input 2 by $15.83 \%$, and input 3 by $1.8 \%$. This has implications for the organization's ability to optimally combine existing resources to achieve maximum output. Thus, controlling inputs and optimizing outputs for non-profit organizations is very important in order to achieve efficiency and good performance.

\section{REFERENCES}

Al-Ayubi, S., Ascarya, \& Possumah, B. T. (2018). "Examining the Efficiency of Zakat Management: Indonesian Zakat Institutions Experiences", International Journal of Zakat, 3(1), 37-55.

Amara, N. B. \& Atia, L. (2016). "Toward the Adoption of A Governance Model in Zakat Foundations: The Case of The Algerian Zakat Funds", International Journal of Business and Management Review, 4(2), 104-118.

Ascarya \& Yumanita, D. (2006). "Comparing the Efficiency of Islamic and Conventional Banks in Malaysia and Indonesia" Working Paper, Center for Central Banking Education and Studies, Bank Indonesia. 
Budiantoro, R. A., Luthfi, F., \& Herianingrum, S. (2018). "Measuring the Efficiency of BAZNAS in Managing Zakat Funds with Stochastic Frontier Approach Analysis, 2002-2016" International Journal of Zakat, 3(1), 89-107.

Charnes, A., Cooper, W.W., \& Rhodes, E. (1978). "Measuring The Efficiency of Decision Making Units", European Journal of Operational Research, 2(6), 429-444. https://doi.org/10.1016/0377-2217(78)90138-8.

Djaghballou, C. E., Djaghballou, M., Larbani, M., Mohamad, A. (2018). "Efficiency and Productivity Performance of Zakat Funds in Algeria", International Journal of Islamic and Middle Eastern Finance and Management, https://doi.org/10.1108/IMEFM-072017-0185.

Hafidhuddin, D. (2011). "Peran Strategis Organisasi Zakat dalam Menguatkan Zakat di Dunia”'Jurnal Ekonomi Islam Al-Infaq, 2(1), 1-4.

Hidayat, R. (2014). Efisiensi Perbankan Syariah: Teori dan Praktik. Jakarta: Gramata Publishing.

Hosen, M. N. \& Rahmawati R. (2016). "Efficiency and Profitability on Indonesian Islamic Banking Industry", Al-Iqtishad Journal of Islamic Economics, 8(1), 33-48. DOI: 10.15408/aiq.v8i1.2507.

Indonesia Magnificence of Zakat. (2010). Indonesia Zakat dan Development Report 2010. Jakarta: IMZ.

Khasanah, U. (2010). Manajemen Zakat Modern. Malang: UIN Maliki Press.

Mubtadi, N. A. \& Susilowati, D. (2018). "Analysis of Governance and Efficiency on Zakat Distribution: Evidence From Indonesia”, International Journal of Zakat, 3(2), 1-15.

Noor, A. H. M., Rasool, M. S. A., Ali, R. M. Y. S. M., \& Rahman, R. A. (2015). "Efficiency of Islamic Institutions: Empirical Evidence of Zakat Organizations' Performance in Malaysia" Journal of Economics, Business and Management, 3(2), 283-286. DOI: 10.7763/JOEBM.2015.V3.195.

Puskas BAZNAS. (2019). Outlook Zakat Indonesia 2019. Jakarta: BAZNAS. Diakses dari https://drive.google.com/file/d/1ZkeHwL8W16j1LeQdCx3OOAoo9Wu258Wz/view

Rustyani, S., \& Rosyidi, S. (2018). "Measurement of Efficiency and Productivity of Zakat Institutions in Indonesia using Data Envelopment Analysis and the Malmquist Productivity Index", International Journal of Zakat, 3(3), 69-8.

Rusydiana, A. S. \& Al-Farisi, S. (2016). "The Efficiency of Zakah Institutions Using Data Envelopment Analysis", Al-Iqtishad Journal of Islamic Economics, 8(2), 213-226. DOI: 10.15408/aiq.v8i2.2876.

Sudibyo, B., (2018). Prospek dan Tantangan Pembangunan Zakat 2019. Jakarta: BAZNAS.

Tanjung, H., \& Devi, A. (2013). Metodologi Penelitian Ekonomi Islam. Jakarta: Gramata Publishing.

Wahab, N. A. \& Rahman, A. R. A. (2011). "A Framework to Analyse the Efficiency and Governance of Zakat Institutions" Journal of Islamic Accounting and Business Research, 2(1), 43-62. DOI 10.1108/17590811111129508.

Wahyuni, I. N. (2016). "The Efficiency of National Zakat Organizations Management Using Data Envelopment Analysis" Journal of Islamic Economics Lariba, 2(1), 1-10. 